Prepared in cooperation with the U.S. Army Corps of Engineers

\title{
Geophysical Data Collected from the St. Clair River between Michigan and Ontario, Canada (2008-016-FA)
}

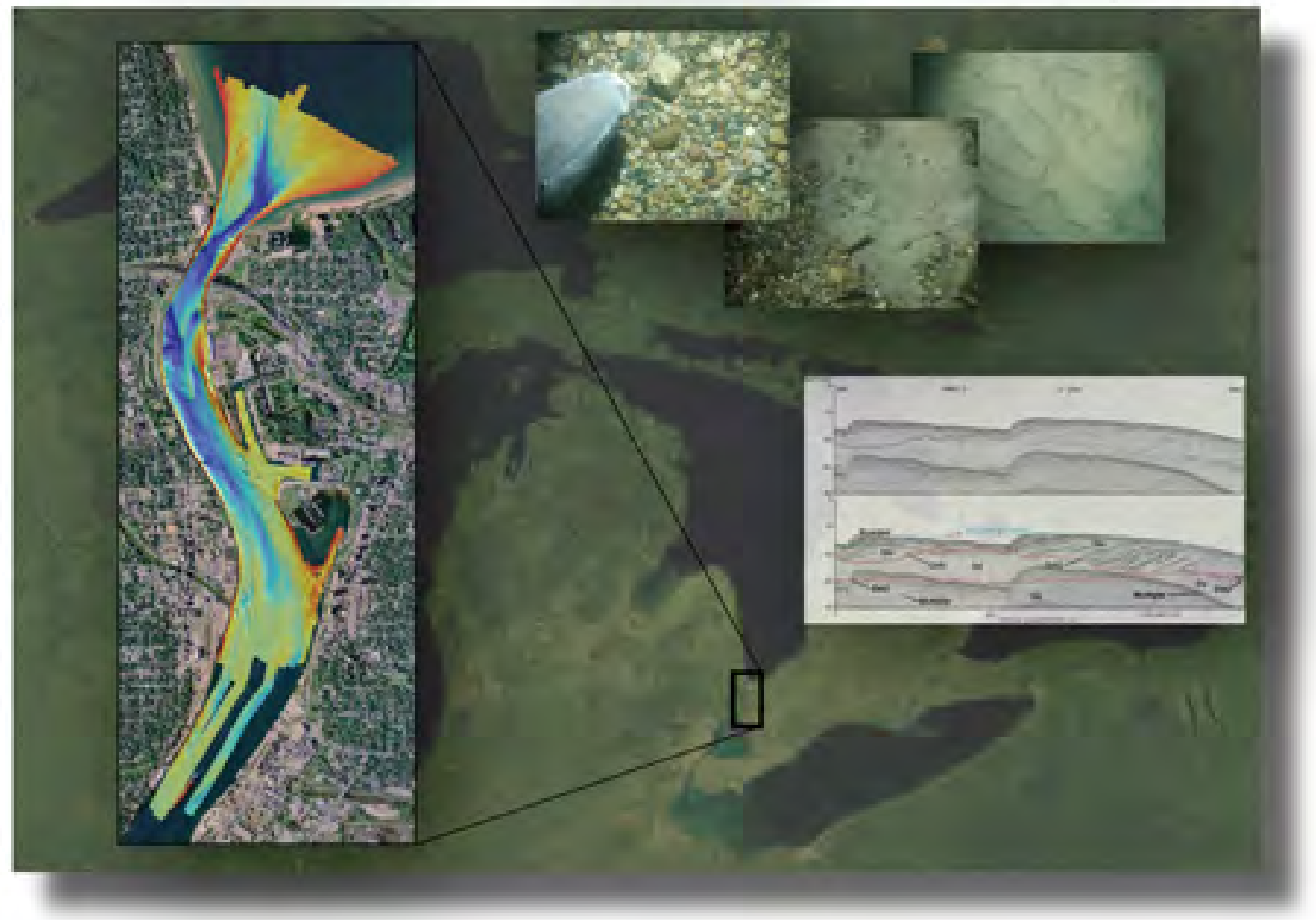

Open-File Report 2010-1035 
Cover. Photograph shows satellite image of the Great Lakes with color-shaded relief image of swath bathymetry, bottom photographs, and boomer seismic data collected by the U.S. Geological Survey, May 29-June 6, 2008. 


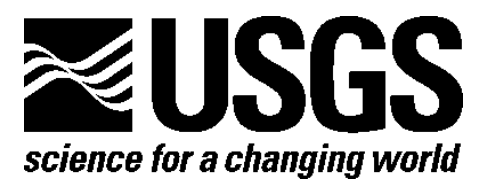

Prepared in cooperation with the U.S. Army Corps of Engineers

\section{Geophysical Data Collected from the St. Clair River between Michigan and Ontario, Canada (2008-016-FA)}

By Jane F. Denny, D.S. Foster, C.R. Worley, and Barry J. Irwin

Open-File Report 2010-1035

U.S. Department of the Interior

U.S. Geological Survey 


\section{U.S. Department of the Interior \\ KEN SALAZAR, Secretary}

\section{U.S. Geological Survey \\ Marcia K. McNutt, Director}

U.S. Geological Survey, Reston, Virginia: 2011

For product and ordering information:

World Wide Web: http://www.usgs.gov/pubprod

Telephone: 1-888-ASK-USGS

For more information on the USGS-the Federal source for science about the Earth,

its natural and living resources, natural hazards, and the environment:

World Wide Web: http://www.usgs.gov

Telephone: 1-888-ASK-USGS

Suggested citation:

Denny, J.F., Foster, D.S., Worley, C.R., and Irwin, B.J., 2011, Geophysical data collected from the St. Clair River between Michigan and Ontario, Canada (2008-016-FA): U.S. Geological Survey Open-File Report 2010-1035, 17 p., at http://pubs.usgs.gov/of/2010/1035/.

Any use of trade, product, or firm names is for descriptive purposes only and does not imply endorsement by the U.S. Government.

Although this report is in the public domain, permission must be secured from the individual copyright owners to reproduce any copyrighted material contained within this report.

The datasets contained in this report have been approved for release and publication by the Directory of the USGS. Although these datasets have been subjected to rigorous review and are substantially complete, the USGS reserves the right to revise the data pursuant to further analysis and review. Furthermore, they are released on condition that neither the USGS nor the United States Government may be held liable for any damages resulting from their authorized or unauthorized use. 


\section{Contents}

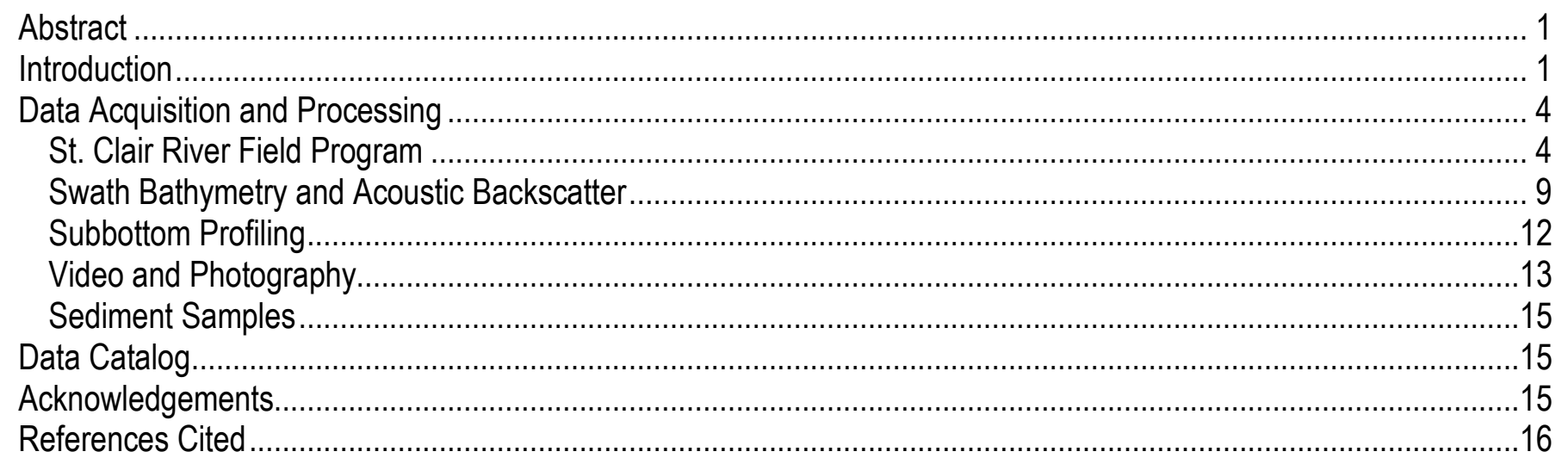

\section{Figures}

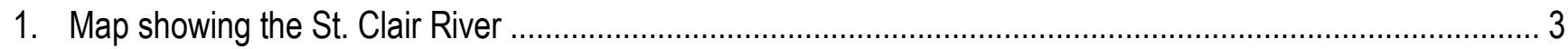

2. Illustration of the geophysical systems used to define the geologic framework ........................................... 5

3. Photograph showing the U.S. Geological Survey RN Rafael with 234-kHz SWATHplus transducers mounted on the bow.

4. Maps displaying the SWATHplus interferometric sonar and Chirp subbottom profiler tracklines and soundvelocity profile locations: $(A)$ in the northernmost St. Clair River area (Klein sidescan-sonar data also were collected along shore-parallel tracklines); (B) at Marysville, Mich.; and (C) at Port Lambton, Ontario .............. 7

5. Map showing tracklines Boomer subbottom tracklines in the northernmost St. Clair River area ..................... 8

6. Color-shaded relief images of the bathymetry collected by the USGS from the St. Clair River ........................10

7. Maps showing the acoustic backscatter collected by the USGS from the St. Clair River ...............................11

8. Photographs showing the U.S. Geological Survey Mini SEABOSS, shown being deployed from the RN Rafael was used to collect sediment samples, and to take video and digital photographs .....................13

9. Map showing location and tracklines of video drifts, locations of individual digital still photographs, and sediment-sampling locations for data acquired with the Mini SEABOSS in the St. Clair River.... 


\section{Conversion Factors and Datum}

SI to Inch/Pound

\begin{tabular}{lcl}
\hline \multicolumn{1}{c}{ Multiply } & By & \multicolumn{1}{c}{ To obtain } \\
\hline centimeter $(\mathrm{cm})$ & Length & \\
millimeter $(\mathrm{mm})$ & 0.3937 & inch (in.) \\
meter $(\mathrm{m})$ & 0.03937 & inch (in.) \\
kilometer $(\mathrm{km})$ & 3.281 & foot (ft) \\
kilometer $(\mathrm{km})$ & 0.6214 & mile (mi) \\
meter $(\mathrm{m})$ & 0.5400 & mile, nautical $(\mathrm{nmi})$ \\
\hline & 1.094 & yard $(\mathrm{yd})$ \\
\hline square kilometer $\left(\mathrm{km}^{2}\right)$ & Area & \\
square meter $\left(\mathrm{m}^{2}\right)$ & 247.1 & acre \\
square kilometer $\left(\mathrm{km}^{2}\right)$ & 10.76 & square foot $\left(\mathrm{ft}^{2}\right)$ \\
\hline & 0.3861 & square mile $\left(\mathrm{mi}^{2}\right)$ \\
\hline meters per second $(\mathrm{m} / \mathrm{s})$ & Flow rate & \\
\hline & 3.281 & foot per second $(\mathrm{ft} / \mathrm{s})$ \\
\hline joule $(\mathrm{j})$ & Energy & \\
\hline
\end{tabular}

Vertical coordinate information is referenced to the International Great Lakes Datum 1985 (IGLD 85).

Horizontal coordinate information is referenced to the World Geodetic System 1984 (WGS 84).

Frequencies are given in hertz $(\mathrm{Hz})$ and kilohertz $(\mathrm{kHz})$. 


\title{
Geophysical Data Collected from the St. Clair River between Michigan and Ontario, Canada (2008-016-FA)
}

\author{
By Jane F. Denny, D.S. Foster, C.R. Worley, and Barry J. Irwin
}

\begin{abstract}
In 2008, the U.S. Geological Survey (USGS), Woods Hole Coastal and Marine Science Center (WHCMSC), in cooperation with the U.S. Army Corps of Engineers conducted a geophysical and sampling survey of the riverbed of the Upper St. Clair River between Port Huron, Mich., and Sarnia, Ontario, Canada. The objectives were to define the Quaternary geologic framework of the riverbed of the St. Clair River to evaluate the relationship between morphologic change of the riverbed and underlying stratigraphy. This report presents the geophysical and sample data collected from the St. Clair River, May 29-June 6, 2008, as part of the International Upper Great Lakes Study, a 5-year project funded by the International Joint Commission of the United States and Canada to examine whether physical changes in the St. Clair River are affecting water levels within upper Great Lakes, to assess regulation plans for outflows from Lake Superior, and to examine the potential effect of climate change on the Great Lakes water levels (http://www.iugls.org). This document makes available the data that were used in a separate report, U.S. Geological Survey Open-File Report 2009-1137, which detailed the interpretations of the Quaternary geologic framework of the region. This report includes a description of the high-resolution acoustic and sediment-sampling systems that were used to map the morphology, surficial sediment distribution, and underlying geology of the Upper St. Clair River during USGS field activity 2008-016-FA (http://quashnet.er.usgs.gov/dta/2008/08016/). Video and photographs of the riverbed were also collected and are included in this data release. Future analyses will be focused on substrate erosion and its effects on river-channel morphology and geometry. Ultimately, the International Upper Great Lakes Study will attempt to determine where physical changes in the St. Clair River affect water flow and, subsequently, water levels in the Upper Great Lakes.
\end{abstract}

\section{Introduction}

In 2007, the International Joint Commission, a body formed by the United States and Canada to manage and protect the lakes and river systems along the U.S. and Canadian border, initiated a 5-year International Upper Great Lakes Study (IUGLS) to investigate the causes and effects of changing lake levels within the Great Lakes basin (Yuzyk and Stahkiv, 2009; http://www.iugls.org/). The Great Lakes region supports large populations, numerous industries, and diverse ecosystems. Changes in lake levels within the Great Lakes region can have major economic and environmental effects. To address these concerns, the IUGLS developed a two-phase approach: (1) to examine the physical processes and changes in the St. Clair River, and its effects on water levels within Lake Michigan-Huran, and (2) review the regulation of Lake Superior outflows and assess the need for improvements to manage evolving uses (Yuzyk and Stahkiv, 2009). To address IUGLS Phase 1 objectives, the USGS in cooperation with the U.S. Army Corps of Engineers (USACOE) conducted a geophysical and sediment 
sampling survey of the Upper St. Clair River to examine the geologic framework and its relation to river-bed morphology.

The St. Clair River is a natural conduit between Lake Michigan-Huron and Lake Erie, and plays a key role in determining water levels within the upper Great Lakes (Yuzyk and Stahkiv, 2009;

http://www.iugls.org/). The St. Clair River is approximately $44 \mathrm{~km}$ in length and flows south from Lake Huron to Lake St. Clair (fig. 1). The USGS survey extended from the lower reaches of Lake Huron to the mouth of the Black River (fig. 1). Two sites to the south at Marysville, Mich., and Port Lambton, Ontario, were also surveyed to provide a comparison to the geologic framework within the Upper St. Clair study area. 


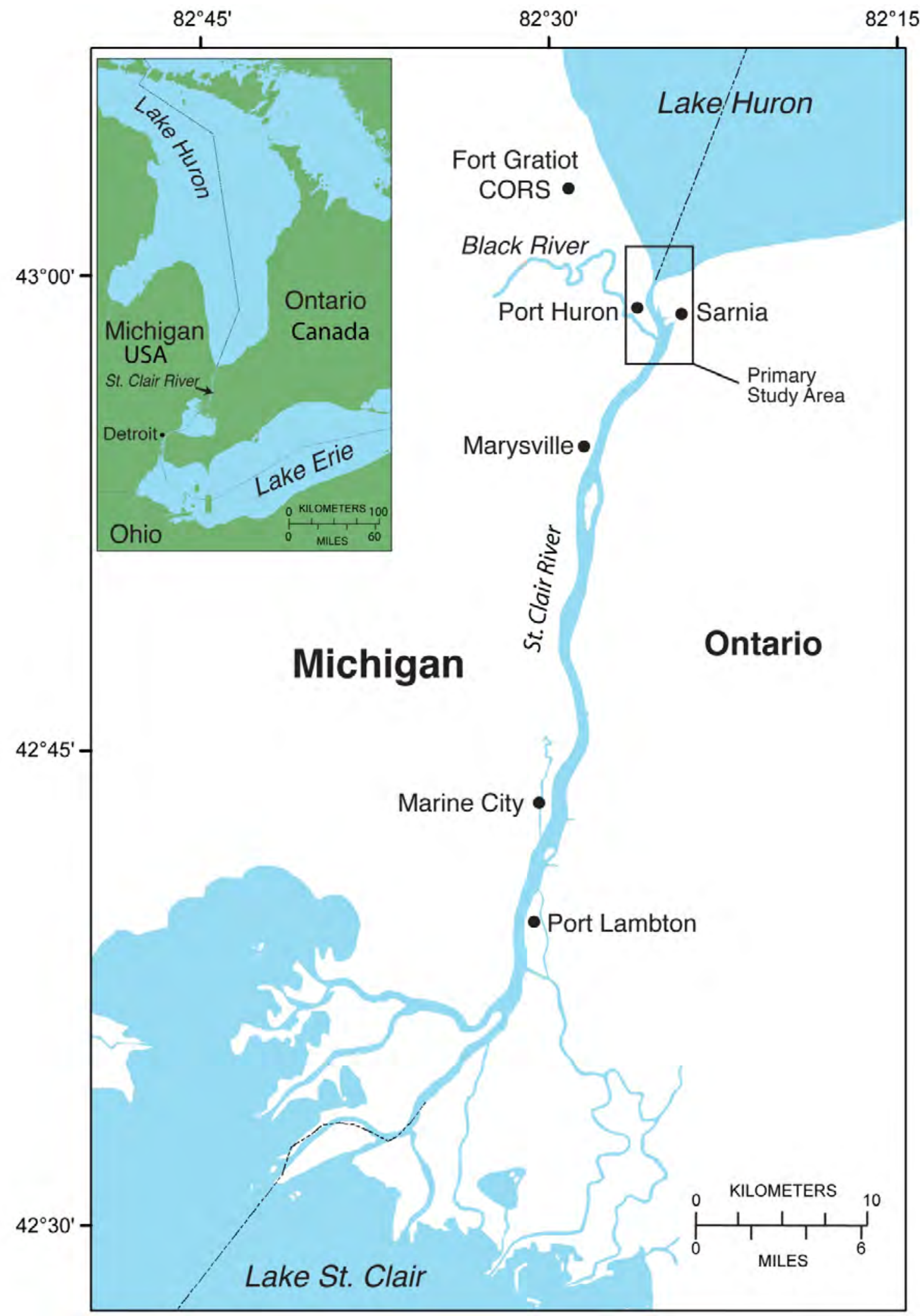

Figure 1. The St. Clair River. The primary study area lies within the northern reaches of the river, with two additional study sites offshore from Marysville, Mich., and Port Lambton, Ontario. Basemap was generated from data supplied by ESRI, ArcGIS 9.2. (After Foster and Denny, 2009). 
This report details the data-processing procedures and presents the geophysical and sample data collected by the USGS from May 29 to June 4, 2008, during USGS field activity 2008-016-FA.

Geophysical data were collected with swath bathymetry, sidescan-sonar, Chirp and Boomer subbottom profilers. Video, photographs, and sediment samples of the riverbed were collected with the USGS Mini SEABed Observation and Sampling System (SEABOSS). A complete presentation and discussion of the geologic framework of the Upper St. Clair River is available in U.S. Geological Survey Open-File Report 2009-1137.

\section{Data Acquisition and Processing}

The following sections provide basic descriptions of shipboard acquisition and geophysical and sample data processing. Detailed descriptions of acquisition parameters, processing steps, and accuracy assessments for each data type are provided in the geospatial metadata (see Data Catalog).

\section{St. Clair River Field Program}

Geophysical data, which were used to image the riverbed and subsurface morphology and sediments, were collected with Chirp and Boomer subbottom profilers, dual-frequency sidescan sonar, and a swath-bathymetric system (fig. 2). Video, photographs, and sediment samples of the riverbed were also collected using the USGS Mini SEABOSS (Blackwood and Parolski, 2001) to provide ground truth for the geophysical data. These systems were deployed from the $R / V$ Rafael (fig. 3), a 7.6-m USGS research vessel operated by the Woods Hole Coastal and Marine Science Center (WHCMSC). Navigation data acquired during cruise operations were recorded by using HYPACK, Hydrographic Survey Software (HYPACK, Inc., 2010). Data were collected from May 29 to June 4, 2008, along tracklines spaced approximately $75 \mathrm{~m}$ apart oriented parallel to the shore, within a region from $2 \mathrm{~km}$ south of the Black River to $1 \mathrm{~km}$ north of the head of the St. Clair River in Lake Huron. Cross-channel survey lines were oriented at perpendicular or oblique angles to the shore-parallel tracklines (figs. 4A and 5). Two site-specific surveys located to the south at Marysville, Mich. (fig. 4B), and Port Lambton, Ontario (fig. 4C), each covered approximately 500-m lengths of the river. These areas were surveyed to compare the geologic framework to the south with that of the northern reaches of the St. Clair River. Sites were chosen based on ongoing studies as part of the IUGLS (Best and others, 2009; Yuzyk and Stakhiv, 2009). 


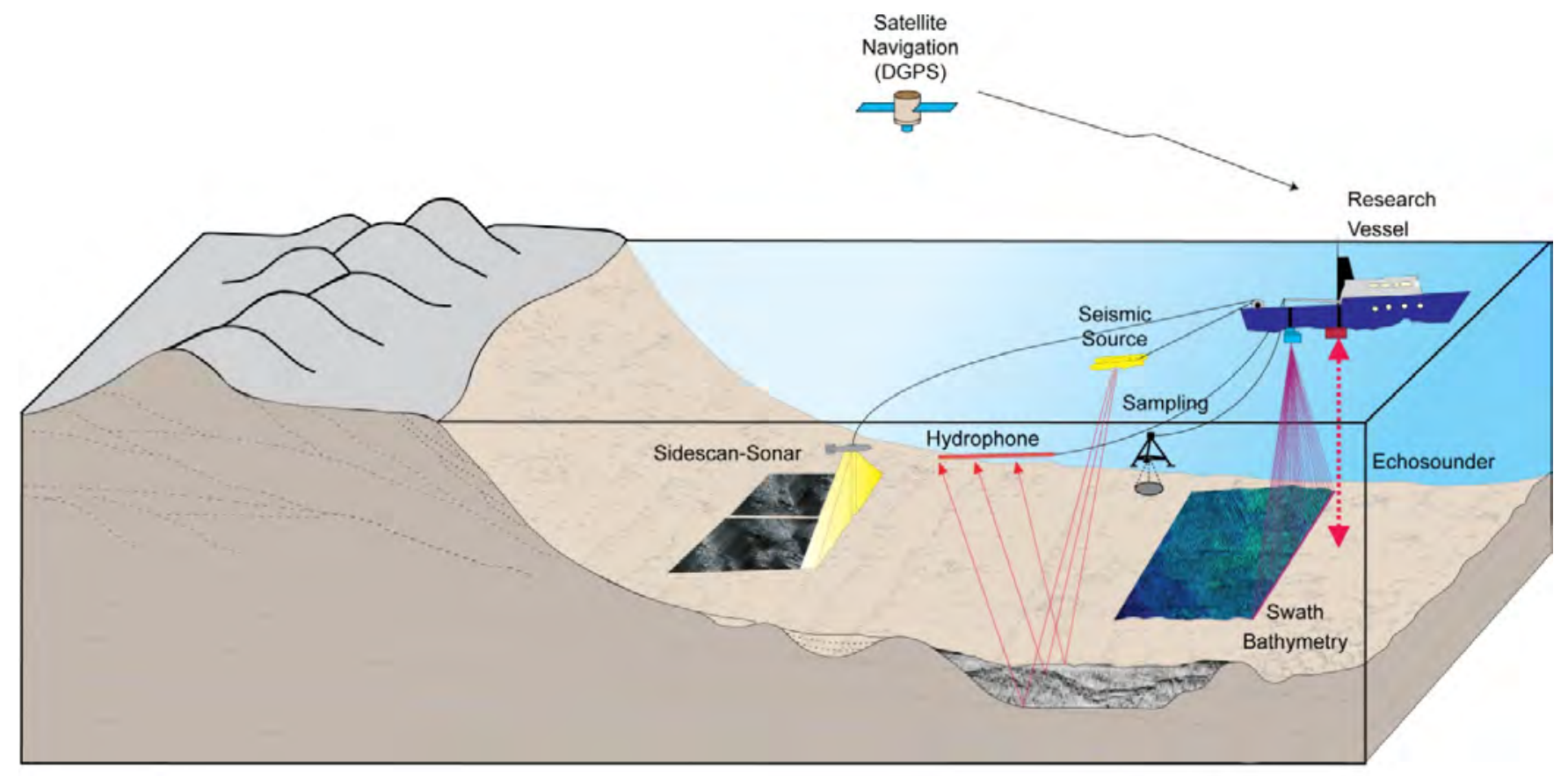

Figure 2. The geophysical systems used to define the geologic framework. Sidescan-sonar, swath-bathymetric, and seismic-reflection systems were used to define the surficial sediment distribution, water depth, and underlying geology. A sediment and image sampling system was used to sample the river-bed sediment. A Differential Global Positioning System (DGPS) was used to navigate the sidescan-sonar and swath bathymetric systems, while a Global Positioning System (GPS) was used to navigate the seismic-reflection system. 


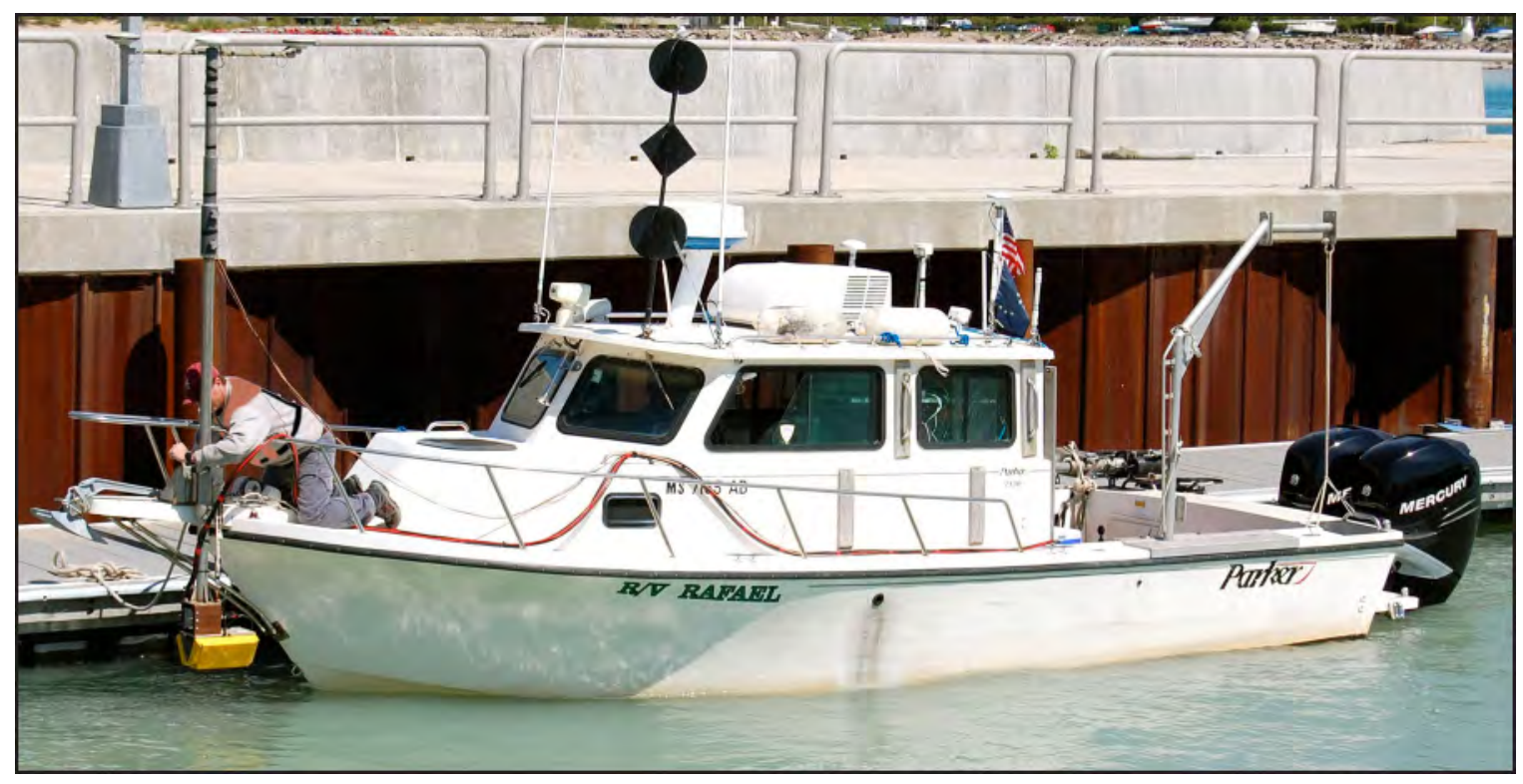

Figure 3. U.S. Geological Survey RN Rafael with 234-kHz SWATHplus transducers mounted on the bow. (Photograph by D. Foster, U.S. Geological Survey). 

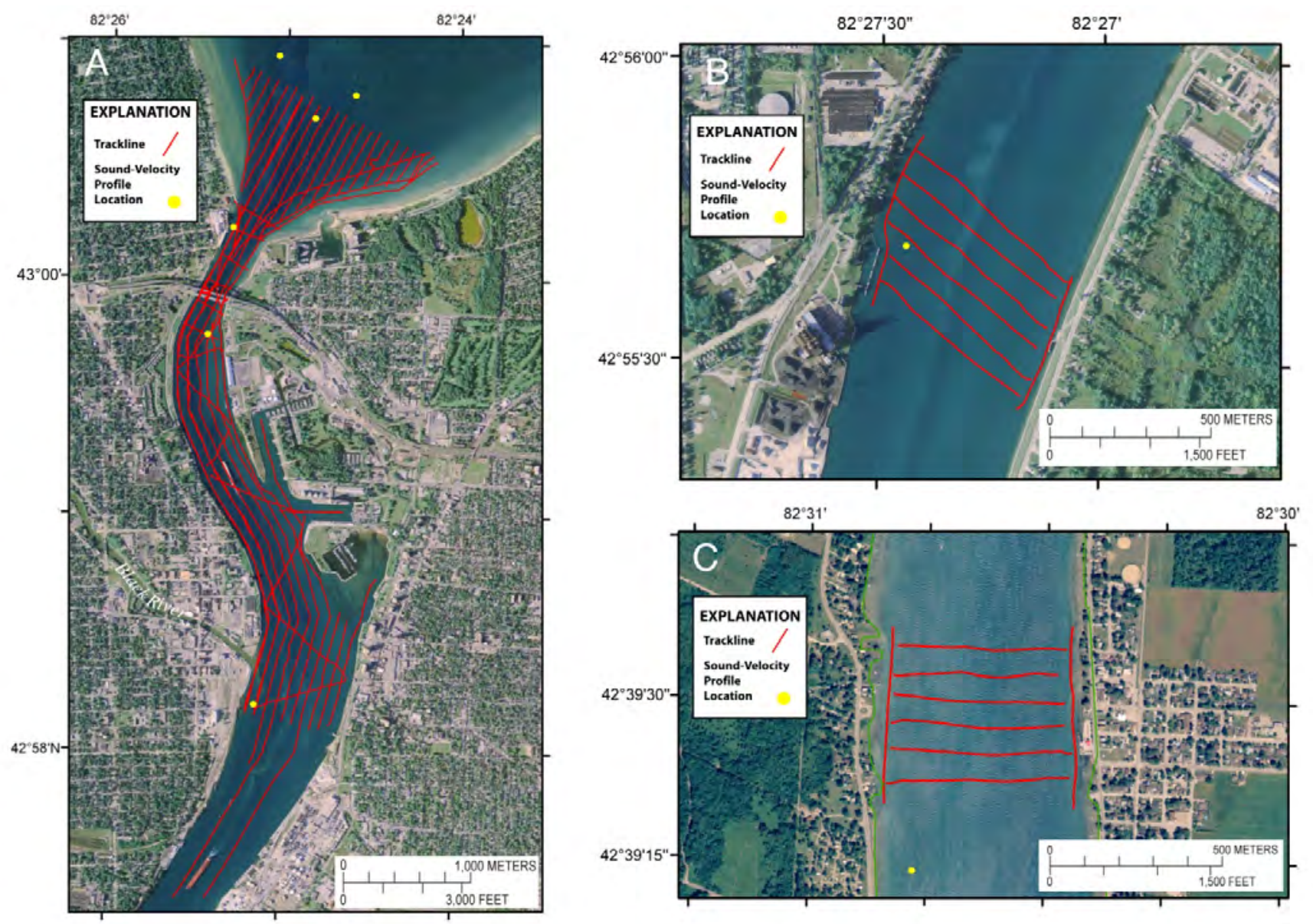

Figure 4. The SWATHplus interferometric sonar and Chirp subbottom profiler tracklines and sound-velocity profile locations: $(A)$ in the northernmost St. Clair River area (Klein sidescan-sonar data also were collected along shore-parallel tracklines); (B) at Marysville, Mich.; and (C) at Port Lambton, Ontario. Tracklines are shown in red and sound-velocity profile locations are shown in yellow. 2005 orthophoto base from Michigan State University, Remote Sensing \& GIS Research and Outreach Services, USDA-FSA Aerial Photography Field Office. (After Foster and Denny, 2009). 


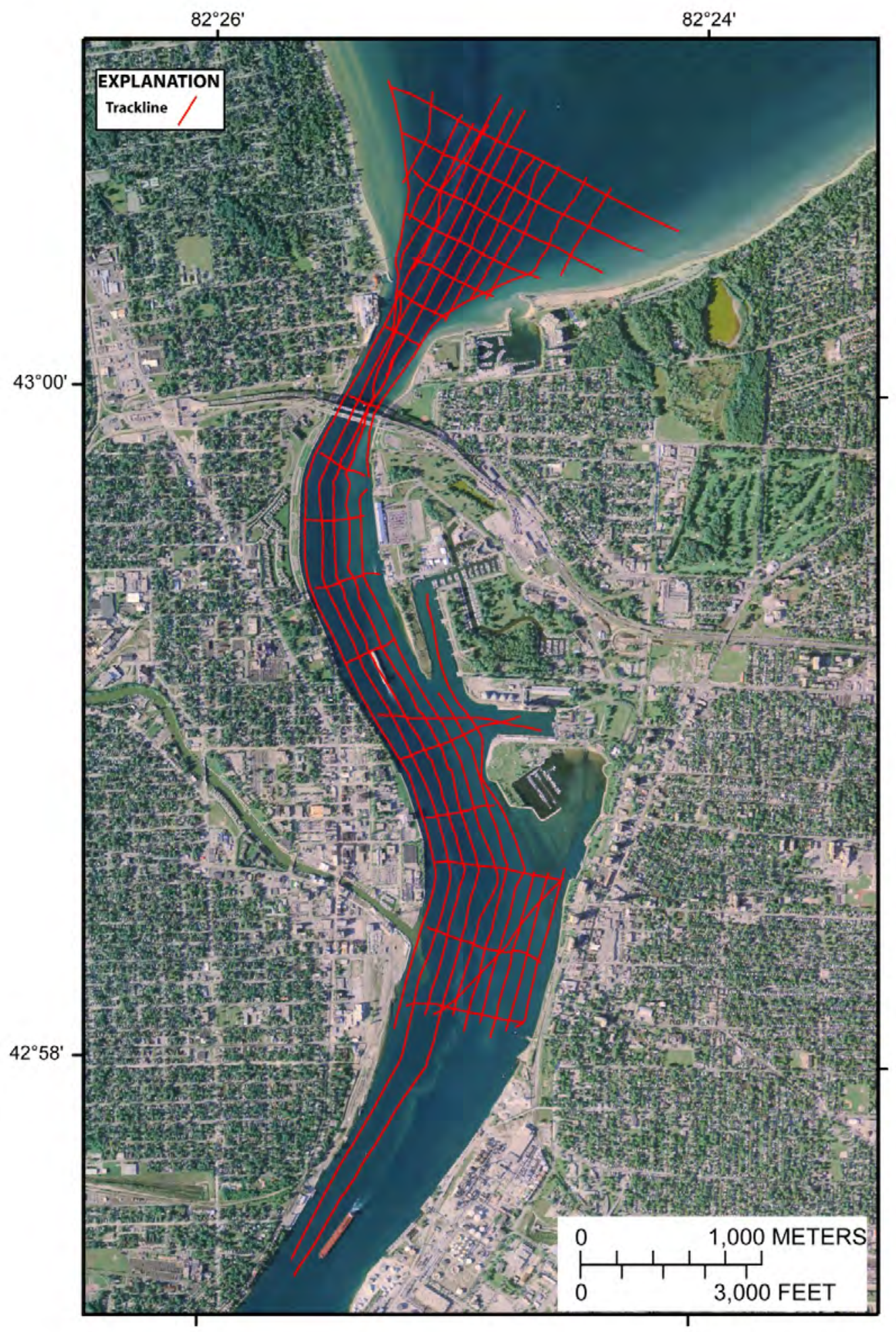

Figure 5. Tracklines Boomer subbottom tracklines in the northernmost St. Clair River area. Tracklines are shown in red. 2005 orthophoto base from Michigan State University, Remote Sensing \& GIS Research and Outreach Services, USDA-FSA Aerial Photography Field Office. (After Denny and Foster, 2009). 


\section{Swath Bathymetry and Acoustic Backscatter}

Swath-bathymetric and acoustic-backscatter data were acquired with a Systems Engineering and Assessment, Ltd. (SEA), SWATHplus interferometric sonar operating at a 234-kHz frequency (SEA, 2009). A total of $109 \mathrm{~km}$ of swath-bathymetric data was collected. The SWATHplus transducer was mounted at the bow of the $R / V$ Rafael (fig. 2). A CODA Octopus F180 Attitude and Positioning system (Coda Octopus Group, Inc., 2009) recorded ship motion (heave, pitch, roll, and yaw) and DGPS corrected navigation. Additional navigation was recorded with a Differential GPS (DGPS) receiver positioned directly over the SWATHplus transducers. Horizontal and vertical offsets between navigation and attitude antennas and the SWATHplus transducer were recorded within the Octopus F180 and SWATHplus configuration files, and the offsets were applied as the data were acquired. SWATHplus data-acquisition software was used to record the bathymetric data at 4,096 samples per swath (ping). Bathymetric data were acquired over variable swath widths that ranged from 10 to $100 \mathrm{~m}$, in water depths of about 1 to $25 \mathrm{~m}$. Eight sound-velocity profiles were acquired during survey operations at roughly 4-hr intervals using an Applied Microsystems SV Plus v2 Velocimeter (Applied Microsystems, 2009) (fig. 4). Variations in the speed of sound within the water column can affect the path of the acoustic ray as it travels from the transducer to the riverbed and back, introducing artifacts in the data. In order to minimize refraction artifacts, sound-velocity profiles were collected throughout the survey area in order to model the sound-velocity structure of the water column.

DGPS navigation was used to record the horizontal and vertical position $(\mathrm{x}, \mathrm{y}, \mathrm{z})$ of bathymetric soundings during data acquisition aboard the $R / V$ Rafael. Real Time Kinematic GPS (RTK-GPS) corrections were applied to the navigation data during post processing to provide submeter horizontal and vertical accuracies of the soundings. Fort Gratiot, Mich., a Continuously Operating Reference Station (CORS) (National Geodetic Survey, 2009), was used as the reference station for the RTK-GPS corrections. A RTK-GPS base station was established at the tidal benchmark at the U.S. Coast Guard Base at Port Huron in order to determine the offset between the North American Vertical Datum of 1988 (NAVD 88) (vertical datum referenced at the CORS site) and the International Great Lakes Datum 1985 (IGLD 1985) referenced at the tidal benchmark. The following offsets were applied to the shipboard DGPS data during processing: the vertical offset between NAVD 88 and IGLD 85, the measured distance between the DGPS antenna and SWATHplus transducer, and the depth of the transducer below the water line. The resulting values were applied to the bathymetric soundings during processing to provide a measure of depth relative to IGLD 85.

Bathymetric data were processed by using SWATHplus (SEA, 2009) and Computer Aided Resource Information System (CARIS) (CARIS, 2009). During processing, data were filtered to remove spurious soundings, rectified for ship motion, and corrected for speed-of-sound changes within the water column (SEA, 2009). RTK-GPS corrections were then applied to the soundings to provide improved vertical resolution and depth relative to IGLD 85 (CARIS, 2009). The processed data were used to generate 1 - and 0.5 -m resolution bathymetric grids (fig. 6). 

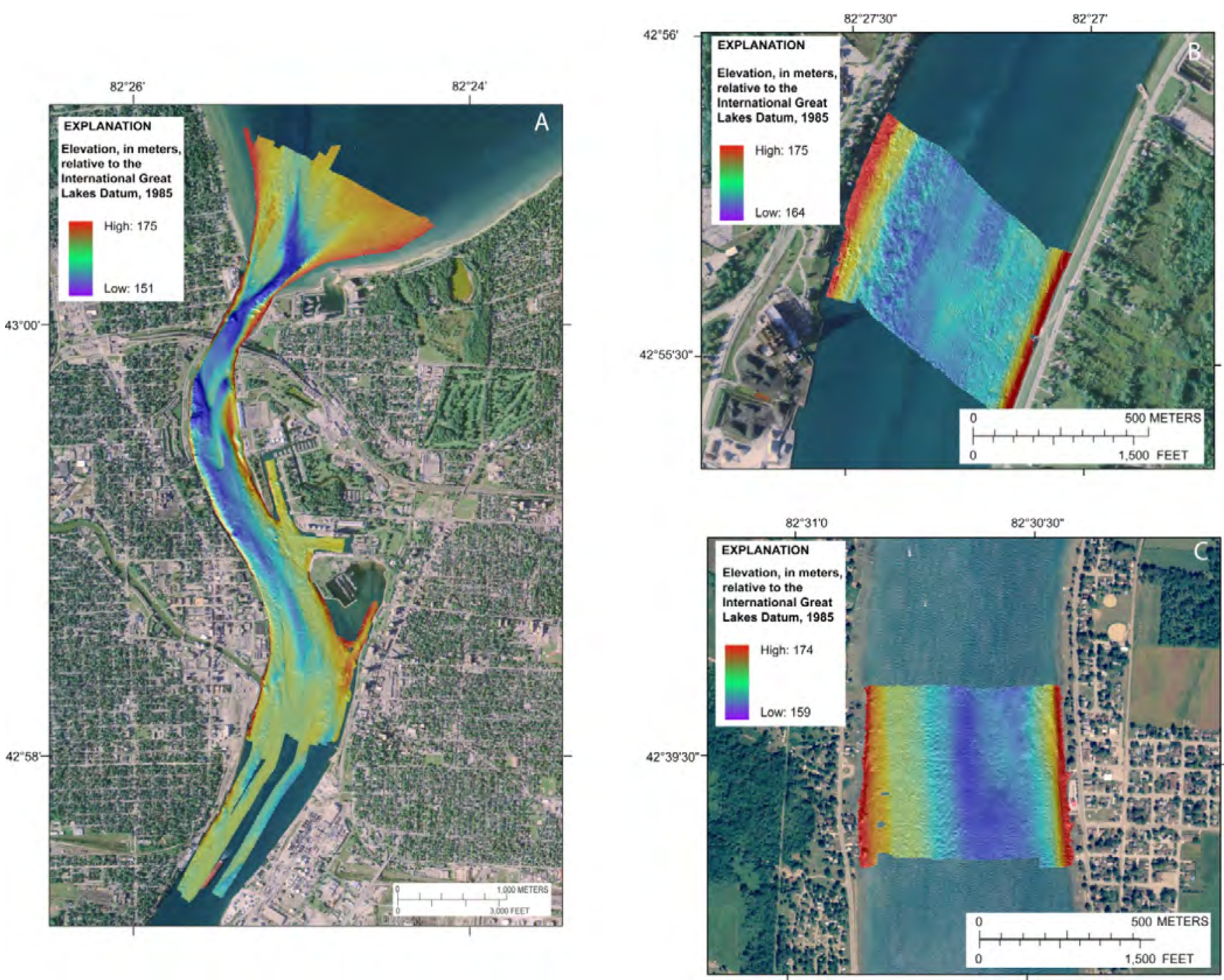

Figure 6. Color-shaded relief images of the bathymetry collected by the USGS from the St. Clair River. All depths are relative to the International Great Lakes Datum, 1985. Hillshade parameters: azimuth is 45 degrees, altitude is 15 degrees, and vertical exaggeration is 2 times. (A) in the northernmost St. Clair River area, depths range from approximately 151 to $175 \mathrm{~m}$; (B) at Marysville, Mich., depths range from approximately 164 to $175 \mathrm{~m}$; and (C) at Port Lambton, Ontario, depths range from approximately 159 to $174 \mathrm{~m} .2005$ orthophoto base from Michigan State University, Remote Sensing \& GIS Research and Outreach Service, USDA-FSA Aerial Photography Field Office. 
Backscatter data were extracted from the raw SWATHplus data files and converted to USGS Xsonar/Showimage file format (Danforth, 1997) by using SwathEd swath-bathymetric processing software (Hughes Clarke, 1998). Radiometric and geometric distortions in the backscatter data were corrected by using Xsonar/Showimage following the methodology of Danforth (1997). A georeferenced acoustic backscatter mosaic was generated at a pixel resolution of $0.5 \mathrm{~m}$ and converted to a TIFF image (Hughes Clarke, 1998). A linear stretch, used to translate the observed digital-number range within the imagery to the full range of the data (a digital number range of 0-255 for an 8-bit grayscale image) was applied to enhance the dynamic range of these data (fig. 7).
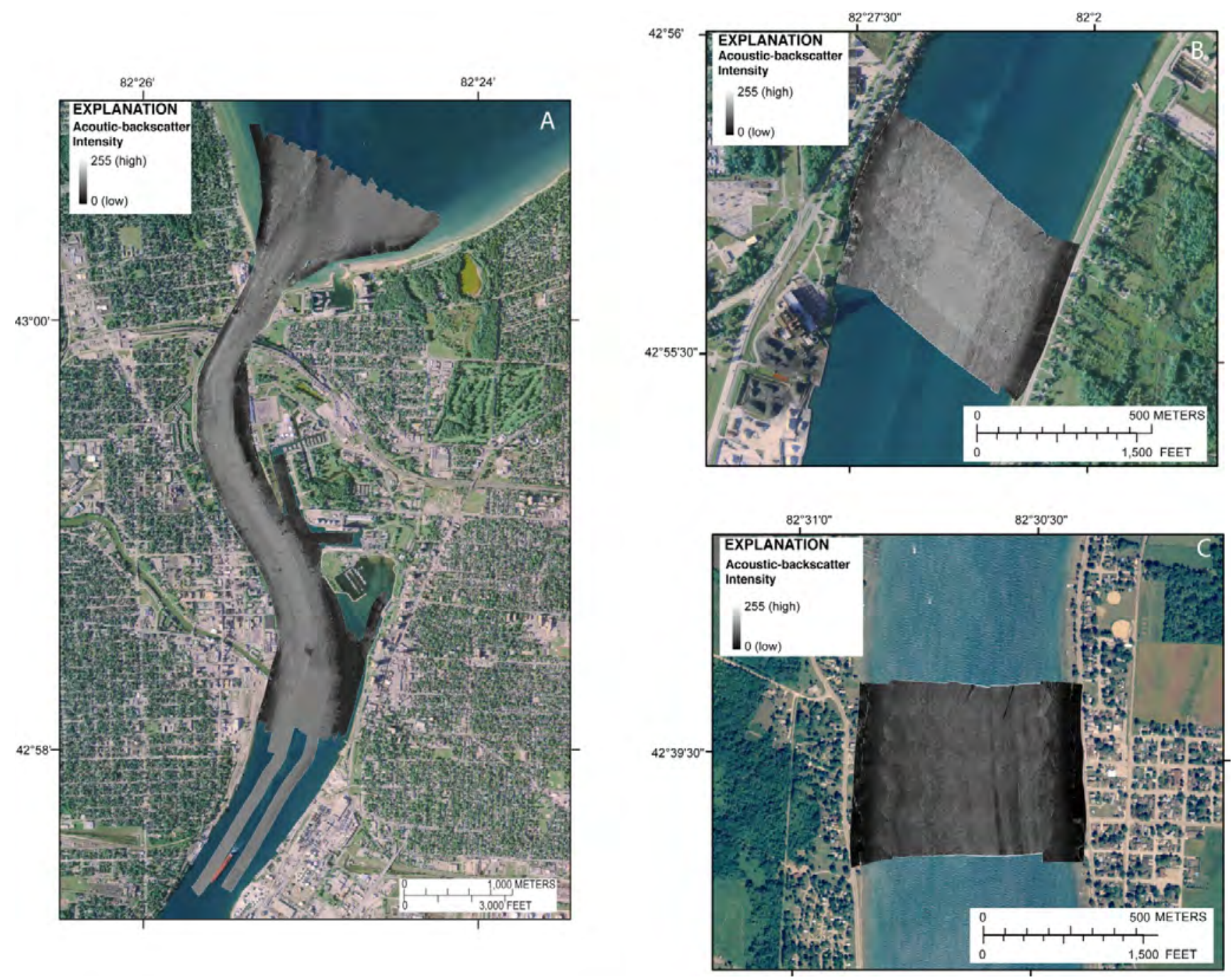

Figure 7. The acoustic backscatter collected by the USGS from the St. Clair River. High acoustic backscatter is displayed as light tones in the imagery and low acoustic backscatter is displayed as dark tones in the imagery. $(A)$ in the northernmost survey area within the St. Clair River; (B) at Marysville, Mich.; and (C) at Port Lambton, Ontario. 2005 orthophoto base from Michigan State University, Remote Sensing \& GIS Research and Outreach Services, USDA-FSA Aerial Photography Field Office. 
A total of $59 \mathrm{~km}$ of sidescan-sonar backscatter data was collected with a Klein Associates, Inc., System 3000 dual-frequency sonar operating at 132- and 445-kHz (Klein Associates, Inc., 2009). The Klein system was deployed off the port side of the $R / V$ Rafael and towed less than $5 \mathrm{~m}$ astern. Horizontal and vertical offsets between the sonar towfish and the DGPS antenna were measured and recorded within SonarPro acquisition software in order to calculate tow-fish position (Triton Imaging, Inc., 2009). Data were collected at 0.033-s sampling rate yielding a 100-m swath width. Data were logged and stored in eXtended Triton format (XTF) by using SonarPro (Triton Imaging, Inc., 2009).

The Klein sidescan-sonar data were processed following the methodology of Danforth and others (1991), Danforth (1997), and Paskevich (1996) to remove radiometric and geometric distortions in the raw data. Processed sonar data were mosaicked following the procedures described in Paskevich (1996) using PCI Geomatics OrthoEngine (PCI Geomatics, 2009). The georeferenced mosaic was projected in Universal Transverse Mercator (UTM) 17N coordinates, referenced to the WGS84 datum at a $0.5-\mathrm{m}$ pixel resolution. The mosaic was saved in TIFF format and a linear stretch was applied.

The SWATHplus and Klein backscatter mosaics were compared to identify the device that provided the highest quality of imagery. The SWATHplus mosaic contained less acoustic noise than the Klein mosaic, most likely due to the mount position of the SWATHplus sonar. The sonar head was mounted on the bow of the $R / V$ Rafael, far enough from the propellers to prevent noise from distorting the sonar signals and the resulting images. The Klein sonar system, however, was towed off the stern of the vessel and was in close proximity to the propellers. As a result, the SWATHplus ${ }^{\circledR}$ mosaic was used for feature identification and interpretation due to the higher quality of the mosaic. The Klein mosaic was not used and is not included in this report.

\section{Subbottom Profiling}

A total of $80 \mathrm{~km}$ of subbottom data was collected by using the Chirp subbottom profiling system (fig. 4), using a dual-frequency (3.5- and 200-kHz) Knudsen Engineering Limited (KEL) Chirp 3200 system (Knudsen Engineering Limited, 2009). The single-beam water depths from the 200-kHz channel were logged together with navigation in ASCII format. Chirp subbottom data with a peak frequency of $3.5 \mathrm{kHz}$ provided a vertical resolution of approximately $30 \mathrm{~cm}$. The Chirp system was fired at a rate of 0.25 or $0.5 \mathrm{~s}$. The trace length was set to $67 \mathrm{~ms}$. The data were recorded in Society of Exploration Geophysicists Y (SEG-Y) format (Barry and others, 1975) with DGPS navigation logged to the SEG-Y file trace headers.

A total of $58.5 \mathrm{~km}$ of subbottom data was collected by using a Boomer subbottom profiling system (fig. 5). Compared to the Chirp, the Boomer system provided a higher energy source operating at 175 joules and provided deeper penetration of the underlying stratigraphy. With a peak frequency of about $1,800 \mathrm{~Hz}$, the vertical resolution was approximately $1 \mathrm{~m}$. The layback distance from the DGPS antenna to the source and receiver was estimated and applied to the position data during acquisition. The Boomer fired at $0.5 \mathrm{~s}$, and recorded each trace with $200 \mathrm{~ms}$ of data. The Boomer data were acquired in SEG-Y format by using SonarWiz.MAP +SBP software (Chesapeake Technology, Inc., 2009). Shotpoint navigation recorded DGPS location in the SEG-Y file trace headers.

Subbottom data were processed by using SIOSEIS (2009) and were loaded into SeisVision ${ }^{\mathrm{TM}}$ (Halliburton, 2009) seismic-interpretation software. The major unconformities were interpreted and digitized. Isochron data were exported and subsequently imported into EarthVision ${ }^{\circledR}$ surface-modeling software (Dynamic Graphics, Inc. ${ }^{\circledR}, 2009$ ). The data points were gridded at a 20- to -20-m cell size. Isochron values were converted to thickness in meters using a constant sediment velocity of $1,650 \mathrm{~m} / \mathrm{s}$. This acoustic velocity correlated well with the depth to bedrock indicated by the geologic cross sections 
near the railway tunnels. We used a 5-m grid derived from our swath-bathymetric data and isopach grids to calculate the elevation (IGLD 85) surfaces.

\section{Video and Photography}

Video and photographs of the river bed were collected at 37 stations by using the USGS Mini SEABOSS (U.S. Geological Survey, 2008; figs. 8 and 9). Mini SEABOSS stations were selected based on preliminary acoustic-backscatter mosaics, with the objective of characterizing broad areas of different backscatter intensity. With the Mini SEABOSS deployed, the research vessel was allowed to drift, with occasional power from the vessel applied to control drift direction. Continuous video was collected over a total of $11.5 \mathrm{~km}$ of lake and riverbed. Video drift position was extracted from the recorded HYPACK navigation files based on the start and end times of the drift. For some portions of the drift, there was no navigation, so the position was derived from the time and position stamp in the video at 30-s intervals. The full-resolution raw video files were archived to DVD-ROM and were then reduced to 640 - to -480 pixels and converted to MPEG-4 format. A total of 449 photographs were obtained from a digital still camera at user-selected locations along the drifts. A Python script was used to merge drift navigation with digital photos using time of day to synchronize the two data sources.

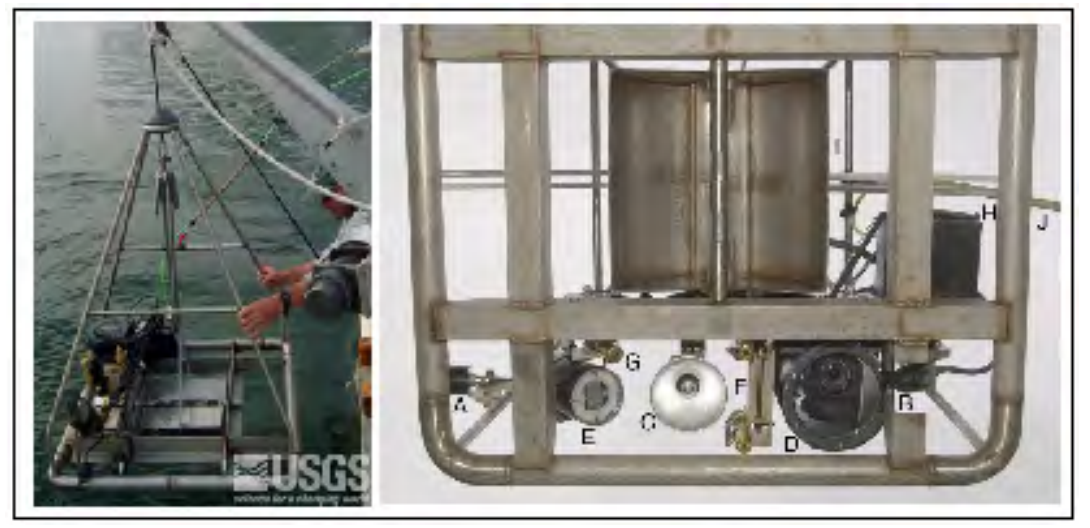

Figure 8. The U.S. Geological Survey Mini SEABOSS, shown (left) being deployed from the RN Rafael was used to collect sediment samples, and to take video and digital photographs. The Mini SEABOSS components viewed from below (right) are: $(A)$ forward video camera; $(B)$ downward video camera; $(C)$ video light; $(D)$ digital still camera and housing; $(E)$ strobe light; $(F)$ parallel lasers for scale; $(G)$ laser for ranging; (H) junction block; (I) Van Veen grab sampler; and (J) multiconducting cable. (Photographs by D. Blackwood, U.S. Geological Survey). 


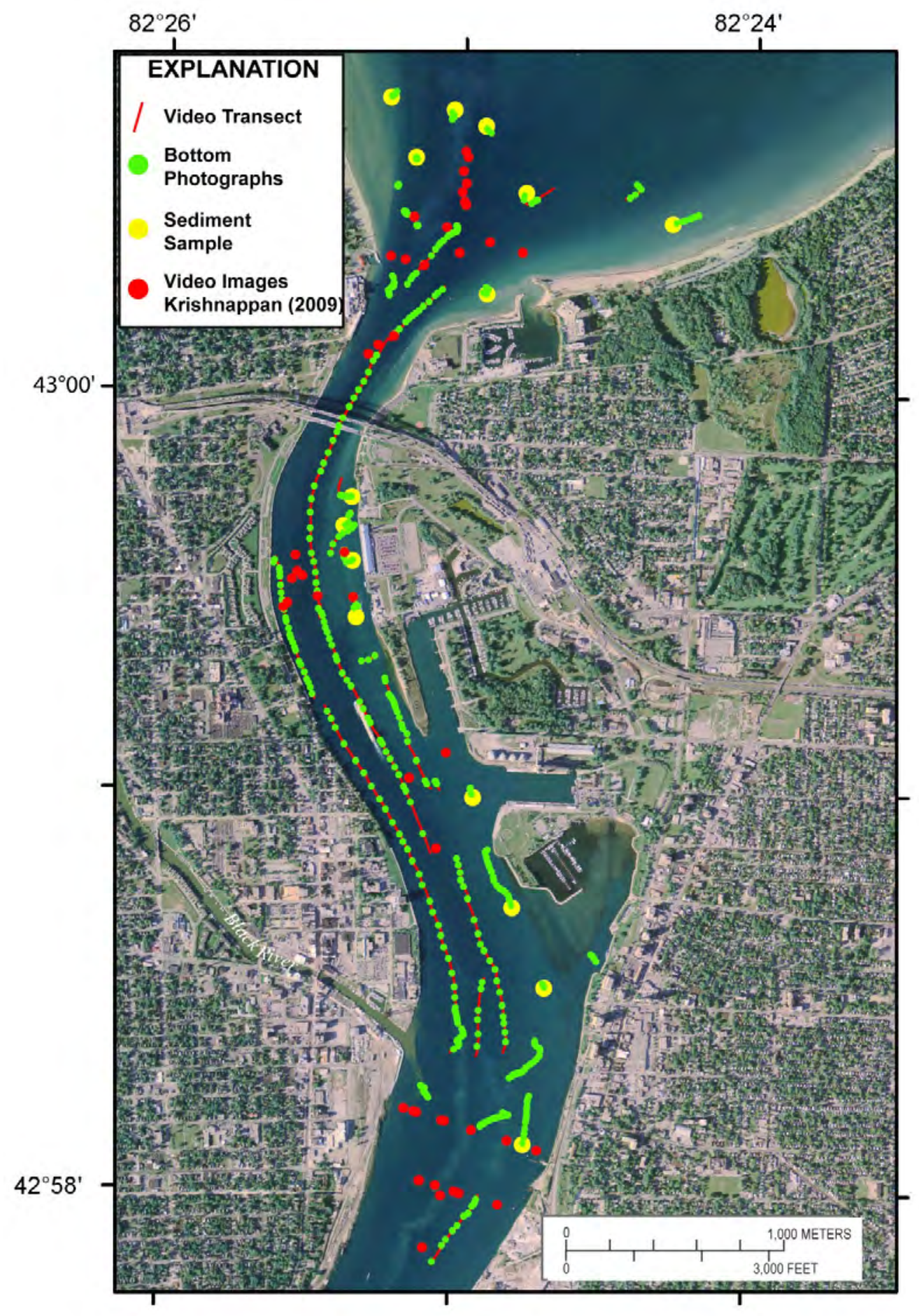

Figure 9. Location and tracklines of video drifts (red lines), locations of individual digital still photographs (green dots), and sediment-sampling locations (yellow dots) for data acquired with the Mini SEABOSS in the St. Clair River. The red dots show locations of selected observations of video along video transects from Krishnappan (2009). 2005 orthophoto base from Michigan State University, Remote Sensing \& GIS Research and Outreach Services, USDA-FSA Aerial Photography Field Office. (After Foster and Denny, 2009). 


\section{Sediment Samples}

Samples of the surficial sediment were collected at 15 stations (fig. 9), using a Van Veen sampler configured on the Mini SEABOSS, typically at the end of a drift. The upper $2 \mathrm{~cm}$ of sediment was scraped from the surface of the sample for texture analysis. Sediment samples were collected at locations with relatively fine-grained sediment (sand or mud). Samples were not collected in gravel or cobble areas where gravel prevented full closure of the sampler and resulted in a washed-out sample.

A total of 13 bottom samples was submitted for grain-size analysis. Two partially recovered, washed-out samples were not submitted. Grain-size analysis was performed at the USGS Sediment Laboratory at WHCMSC by using methods described by Poppe and others (2005).

\section{Data Catalog}

This report contains geospatial data in vector and raster formats. The vector data are available in Environmental Systems Research Institute (ESRI) shapefile format. Raster data are available in ESRI binary grid format, ASCII format or GeoTIFF image format. A TIFF world file (*.tfw) is provided as additional georeferencing information for the GeoTIFF image format.

\section{Projection Information:}

Raster data: UTM meters, zone 17N, WGS84 Datum.

Vector data: Geographic Coordinate System, WGS84 Datum.

\section{Metadata:}

Federal Geographic Data Committee compliant metadata are available for the geospatial data contained within this report. The metadata are viewable in several formats: TEXT, HTML and FAQ.

\section{Download}

The data can be accessed in several ways depending on software availability:

* ArcGIS 9.2 or higher

* ArcGIS Explorer (available at no cost: http://www.esri.com/software/arcgis/explorer/index.htm)

Data and associated metadata files are compressed within zip files in order to facilitate downloads. WinZip (http://www.winzip.com) files of the individual data layers are linked within the table below.

This report is available on DVD-ROM upon request. An ArcMap 9.2 map document file (of2010-1035.mxd) containing the geospatial data presented below is provided on the DVD-ROM. Cruise, sample and video logs are also contained within this report in the log directory.

\section{Acknowledgements}

This study was conducted by the USGS in cooperation with the U.S. Army Corps of Engineers as a component of the International Upper Great Lakes Study. The U.S. Coast Guard Station at Port Huron provided dockage and facilities for mobilization. This report was improved by technical reviews by USGS personnel Benjamin Gutierrez, Brian Andrews, and VeeAnn Cross. 


\section{References Cited}

Applied Microsystems, 2009, Sound velocity-SV Plus v2: Applied Microsystems, accessed July 1, 2009, at http://www.appliedmicrosysstems.com/products/productDetails.aspx?id=1

Barry, K.M., Cavers, D.A., and Kneale, C.W., 1975, Report on recommended standards for digital tape formats: Geophysics, v. 40, no. 02, p. 344-352. Also available at http://www.seg.org/SEGportalWEBproject/prod/SEG-Publications/Pub-TechnicalStandards/Documents/seg_y_rev0.pdf

Best, J., Oberg, K., Czuba, J., and Parsons, D., 2009, Mapping morphology and flow in the upper St. Clair River, International Upper Great Lakes Study: On the Level, issue 3, March 2009, p. 2-3, accessed June 23, 2009, at http://pub.iugls.org/en/Other_Publications/OnTheLevel_spring_2009.pdf

Blackwood, D., and Parolski, K., 2001, Seabed observation and sampling system: Sea Technology, v. 42 , no. 2 , p. $39-43$.

Chesapeake Technology, Inc., 2009, SonarWiz.MAP +SBP: Chesapeake Technology, Inc., accessed June 23, 2009, at http://www.chesapeaketech.com/prod-plussbp.html.

Coda Octopus Group, Inc., 2009, Octopus F180 Attitude and Positioning System: Coda Octapus, accessed July 1, 2008, at http://www.codaoctopus.com/motion/f180/index.asp

Computer Aided Resource Information System (CARIS), 2009, Geomatics Software Solutions, CARIS: HIPS and SIPS: CARIS, accessed July 1, 2009, at http://www.caris.com/products/hips-sips

Danforth, W.W., 1997, Xsonar/ShowImage, a complete system for rapid sidescan sonar processing and display: U.S. Geological Survey Open-File Report 97-686, available at http://pubs.er.usgs.gov/usgspubs/ofr/ofr97686.

Danforth, W.W., O’Brien, T.F., and Schwab, W.C., 1991, USGS image processing system: near realtime mosaicking of high-resolution sidescan-sonar data: Sea Technology, p. 54-59.

Dynamic Graphics, Inc., 2009, EarthVision-Dynamic Graphics EarthVision technology: Dynamic Graphics, Inc., accessed May 6, 2009, at http://www.dgi.com/earthvision/evmain.html.

EdgeTech, 2009, EdgeTech: sub-bottom profilers and topsides \& software: EdgeTech, accessed July 1, 2009, at http://www.edgetech.com/productlinemarine.html

Foster, D.S., and Denny, J.F., 2009, Quaternary geologic framework of the St. Clair River between Michigan and Ontario, Canada: U.S. Geological Survey Open-File Report 2009-1137, available at http://pubs.usgs.gov/of/2009/1137.

Halliburton, 2009, Halliburton-GeoGraphix: Hallibutron, accessed June 23, 2009, at http://www.geographix.com/PDFs/GGX_tech.pdf.

Hughes Clarke, J., 1998, SwathEd-A deranged software toolkit developed by John Hughes Clarke: Ocean Mapping Group, University of New Brunswick, accessed May 6, 2009, at http://www.omg.unb.ca/ jhc/SwathEd.html.

HYPACK, Hydrographic Survey Software, accessed June 2010, at http://hypack.com/. Interactive Visualization Systems (IVS): IVS, accessed July 1, 2009, at http://www.ivs3d.com

International Upper Great Lakes Study, 2009, International Upper Great Lakes Study: International Upper Great Lakes Study, accessed June 2010, at http://www.iugls.org.

Klein Associates, Inc., 2009, Klein System 3000 Sonar System: Klein Associates, accessed July 1, 2009, at http://www.1-3klein.com/3000series/3000.html

Knudsen Engineering Limited, 2009, Knudsen Engineering Limited—Chirp 3200 echosounder:

Knudsen Engineering Limited, accessed May 6, 2009, at

http://knudsenengineering.com/html/products/chirp3200.html 
Krishnappan, B., 2009, Sediment transport regime of St. Clair River: International Upper Great Lakes Study, accessed June 23, 2009, at http://pub.iugls.org/en/St_Clair_Reports/Sediment/ SD-1\%20and\%202.pdf

National Geodetic Survey, 2009, National Geodetic Survey_CORS-Continuously Operating Reference Stations: National Geodetic Survey, accessed June 2010, at http://www.ngs.noaa.gov/CORS/.

Paskevich, V.F., 1996, MAPIT: An improved method for mapping digital sidescan sonar data using the Woods Hole Image Processing System (WHIPS) Software: U.S. Geological Survey Open-File Report 96-281.

PCI Geomatics, PCI Geomatics: PCI Geomatics, accessed July 1, 2009, at http://www.pcigeomatics.com

SIOSEIS, 2007, SIOSEIS-The introduction: SIOSEI, accessed July 1, 2008, at http://sioseis.ucsd.edu/sioseis.html.

Stockwell, J.W., Jr., and Cohen, J.K., 2007, The New SU User's Manual (version 3.3): Golden, Colo., Colorado School of Mines-Center for Wave Phenomena, $153 \mathrm{p}$.

Systems Engineering \& Assessment, Ltd. (SEA), 2009, SWATHplus-Wide Swath Bathymetry \& Sidescan: SE, Ltd., accessed July 1, 2009, at http://www.sea.co.uk/swathpluspi.aspx?nav=products Triton Imaging, Inc., 2009, Triton imaging techweb: Technical information, user guides and more: Triton Imaging, Inc., accessed May 6, 2009, at http://www.tritonimaginginc.com/site/content/public/downloads/Guides/.

Yuzyk, T.R., and Stakhiv, E.Z., eds., 2009, International Upper Great Lakes study, impacts on Upper Great Lakes water levels: St. Clair River, Final report to the International Joint Commission: International Upper Great Lakes study, December 2009, p. 224. 
Prepared by the Pembroke Publishing Service Center.

For more information concerning this report, contact:

Director

U.S. Geological Survey

Woods Hole Coastal and Marine Science Center

384 Woods Hole Road

Quissett Campus

Woods Hole, MA 02543-1598

WHSC_science_director@usgs.gov

508-548-8700 or 508-457-2200

or visit our Web site at:

http://woodshole.er.usgs.gov/ 
